\title{
Komisaris Independen sebagai Pemoderasi Pengaruh Intensitas Modal dan Biaya Utang terhadap Agresivitas Pajak
}

\author{
Baiq Fitri Arianti ${ }^{1}$
}

1 Universitas Pamulang, Tangerang Selatan, Banten

DOI: https://doi.org/10.35838/jrap.2021.008.02.15

ARTICLE INFO
JEL Classification:
H25; O16
Key words:
tax aggressiveness, capital
intensity, cost of debt,
independent commissioner

\section{PENDAHULUAN}

Sumber pendapatan terbesar bagi suatu Negara adalah pajak. Pajak menjadi unsur penting yang diatur Undang-Undang Republik Indonesia No 28 tahun 2007 pasal 1 ayat (1) yaitu, pajak adalah kontribusi wajib kepada Negara yang terutang oleh orang pribadi atau badan yang bersifat memaksa berdasarkan undang-undang, dengan tidak mendapatkan imbalan secara langsung yang digunakan untuk keperluan bagi Negara sebesar-besarnya. Data terkini menunjukkan

\begin{abstract}
This reseacrh to determine the direct and indirect effects of Capital Intensity and Cost of Debt mediated by Tax Aggressiveness on Independent Commissioners. The type of research used is descriptive quantitative research. Collecting data through literature study and documentation study through reports downloaded through the website on the Indonesia Stock Exchange using proposive sampling technique. The sample in this study amounted to 13 companies. The data analysis method used is data analysis through E-views 9 software. The results of this study indicate that capital intensity has a positive and significant effect on tax aggressiveness, the cost of debt does not significantly affect tax aggressiveness, independent commissioners cannot moderate or weaken the relationship between capital intensity and aggressiveness. tax. Meanwhile, independent commissioners can moderate or strengthen the relationship between the cost of debt and tax aggressiveness.
\end{abstract}

\begin{abstract}
ABSTRAK
Penelitian ini bertujuan untuk mengetahui pengaruh langsung dan tidak langsung dari Intensitas Modal dan Biaya Utang yang dimediasi oleh tindakan Agresivitas Pajak terhadap Komisaris Independen. Jenis penelitian yang digunakan adalah penelitian kuantitatif deskriptif. Pengumpulan data melalui studi pustaka dan studi dokumentasi melalui laporan yang diunduh melalui website di Bursa Efek Indonesia dengan menggunakan teknik proposive sampling. Sampel dalam penelitian ini berjumlah 13 perusahaan. Metode analisis data yang digunakan analisis data melalui software E-views 9. Hasil dari penelitian ini menunjukkan Intensitas modal berpengaruh positif dan signifikan terhadap agresivitas pajak, biaya utang tidak berpengaruh signifikan terhadap agresivitas pajak, komisaris independen tidak dapat memoderasi atau memperlemah hubungan intensitas modal terhadap agresivitas pajak. Sedangkan komisarisi independen dapat memoderasi atau memperkuat hubungan biaya utang terhadap agresivitas pajak.
\end{abstract}

bahwa penerimaan pajak hingga April 2021 mencapai Rp 374,9 triliun. Penerimaan tersebut tercatat $30,94 \%$ dari target penerimaan pajak tahun 2021 sebesar Rp $1.229,6$ triliun. Realisasi tersebut tumbuh sebesar negatif $0,46 \%$. Jika dibandingkan dengan penerimaan pajak pada tahun sebelumnya, pertumbuhan ini sudah lebih baik karena tahun lalu bulan April, penerimaan pajak kontruksinya minus 3\%, hal tersebut dikarenakan adanya faktor shortfall berkisar Rp 126,7\% triliun yang memiliki andil 
terhadap membengkaknya realisasi pembiayaan anggaran sebesar Rp 945,8 triliun dan faktor lainnya adalah penanganan pandemi covid 19 dan pemulihan ekonomi yang membutuhkan biaya besar.

Bagi perusahaan pajak bersifat memaksa, karena pemerintah memaksa agar perusahaan membayar pajak, sedangkan tujuan dari perusahaan adalah menciptakan laba. Dengan perusahaan membayar pajak akan dapat mempengaruhi laba yang di peroleh. Oleh karena itu biasanya perusahaan meminimalisir beban pajak dengan melakuan tindakan agresif pada pajak atau sering di sebut dengan Agresivitas Pajak. Menurut Mustika (2017) mengatakan agresivitas pajak perusahaan yaitu keinginan untuk mengecilkan jumlah beban pajak yang harus dibayar baik dengan cara legal (Tax Avoidance) ataupun illegal (Tax Evasion) dengan memanfaatkan celah-celah yang ada dalam perpajakan.

Fenomena dalam penelitian ini terjadi pada tahun 2019 PT Bentoel Internasional Investama terindikasi melakukan tindakan penghindaran pajak. Lembaga Tax Justice Network menyampaikan dalam laporan tertulis, melaporkan bahwa PT Bentoel Internasional Investama telah mengalihkan sebagian pendapatannya keluar dari Indonesia dengan cara pinjaman intra perusahaan. Bentoel banyak mengambil pinjaman antara tahun 2013 sampai tahun 2015 dari perusahaan Belanda sebesar Rp 5,5 triliun pada agustus 2013 dan Rp 6,7 trilliun pada 2015, sehingga PT bentoel harus membayar total bunga pinjaman sebesar Rp 2,25 triliun. Bentoel terindikasi melakukan pinjaman agar dapat menghindari potongan pajak untuk pembayaran bunga kepada non penduduk. Indonesia menerapkan pemotongan pajak tersebut sebesar 20\%, namun karena ada perjanjian dengan Belanda maka pajaknya menjadi 0\%. Dari strategi tersebut, Indonesia kehilangan pendapatan bagi negara sebesar 11 juta dolar AS pertahun. Pasalnya dari utang 164 juta dollar AS. Indonesia, harusnya mengenakan pajak $20 \%$ atau 33 juta dolar AS atau 11 juta dolar AS pertahun.

Solusi dari permasalahan diatas bahwa seharusnya pihak manajemen perusahaan dari PT. Bentoel Investama Internasional lebih melakukan pengawasan terhadap sistem pelaporan perpajakan dengan memperbanyak jumlah dewan komisaris independen agar sistem pengawasan lebih terjaga sehingga tidak terjadi tindakan Agresivitas Pajak dan pemerintah lebih baik memperbarui undangundang mengenai pajak terutama pada kelemahan-kelemahan yang mungkin saja bisa disalahgunakan oleh perusahaan penghindar pajak.

Intensitas modal dan biaya utang merupakan faktor yang mempengaruhi perusahaan melakukan tindakan agresivitas pajak. Dimana diliat dari perusahaan menanamkan investasinya dalam bentuk asset. Didalam asset tetap bisa memperliatkan seberapa besarnya kekayaan yang di peroleh suatu perusahaan, karena jika semakin besar investasi dalam perusahaan terhadap asset tetap, maka semakin besar juga menanggung beban depresiasi, dari beban tersebut akan berpengaruh terhadap kewajiban perpajakan perusahaan. Biaya utang juga merupakan faktor yang mempengaruhi perusahaan melakukan tindakan agresivitas pajak. Menurut Supramono (2012), menyatakan bahwa perusahaan menggunakan utang untuk membiyai investasi, dalam kaitannya dengan pajak, perilaku ini disebabkan karena bunga merupakan bahan tetap yang dapat mengurangi pajak. Sehingga keberadaan komisaris independen didalam suatu perusahaan dijadikan alasan dalam penentuan variabel pemoderasi. Dengan adanya indikasi tersebut keberadaan komisaris independen dalam perusahaan berperan penting, dimana dapat mengawasi setiap tindakan yang diambil oleh manajemen perusahaan. Berdasarkan uraian yang telah dikemukakan diatas, penulis ingin mengetahui mendalam mengenai mengenai pengaruh intensitas modal dan biaya utang yang dimediasi oleh agresivitas pajak terhadap komisaris independen. 


\section{TELAAH TEORI DAN \\ PENGEMBANGAN HIPOTESIS}

Menurut Ginting (2016) Komisaris Independen adalah anggota dewan komisaris yang tidak terafiliasi dengan direksi, anggota dewan komisarsis lainnya dan pemegang saham pengendali, serta bebas dari hubungan bisnis atau hubungan lainnya yang dapat mempengaruhi kemampuannya untuk bertindak independen atau bertindak sematamata demi kepentingan perusahaan. Menurut Darsono (2015) Intensitas modal merupakan banyaknya modal milik perusahaan dengan wujud asset tetap yang dijadikan sebagai investasi perusahaan. Capital intensity yiatu kegiatan investasi perusahaan dalam bentuk asset tetap. Menurut Arianti (2019) Biaya Utang atau cost of debt merupakan tingkat pengembalian yang diinginkan oleh kreditur saat memberikan pendanaan kepada perusahaan ketika melakukan peminjaman. Menurut Mustika (2017) mengatakan agresivitas pajak perusahaan yaitu keinginan untuk mengecilkan jumlah beban pajak yang harus dibayar baik dengan cara legal (Tax Avoidance) ataupun illegal (Tax Evasion) dengan memanfaatkan celah-celah yang ada dalam perpajakan.

\section{Kerangka konseptual}

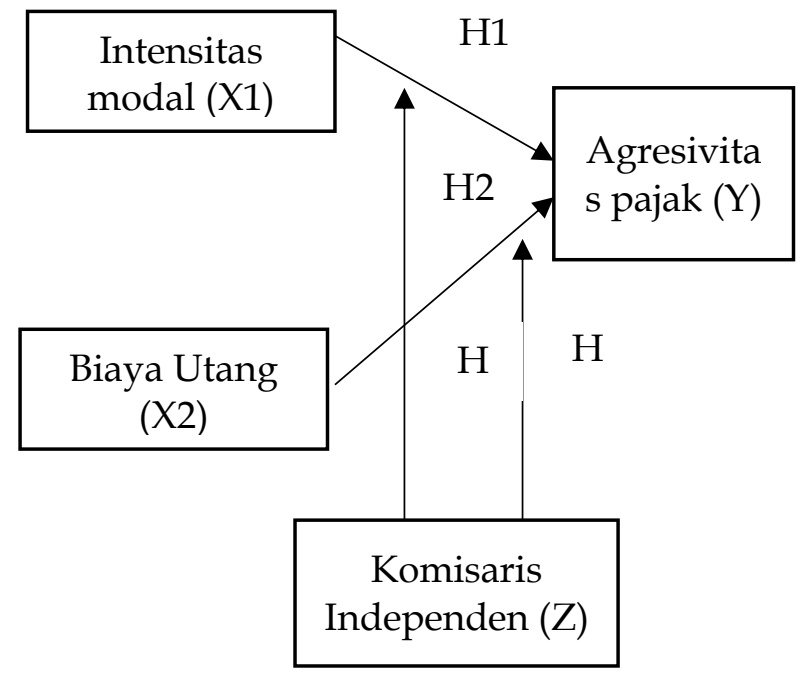

Gambar 1. Kerangka Konseptual

\section{PENGEMBANGAN HIPOTESIS}

\section{Intensitas modal berpengaruh terhadap} agresivitas pajak

Upaya memaksimalkan produksi dapat dilakukan melalui kebijakan intensitas modal. Intensitas modal merupakan ukuran banyaknya modal milik perusahaan dengan wujud aset tetap yang dijadikan sebagai investasi perusahaan (Muzakki \& Darsono, 2015). Saat kepemilikan aset perusahaan berada dengan jumlah besar, maka semakin besar pula biaya penyusutannya. Biaya penyusutan adalah pengalokasian nilai manfaat ekonomis aset dalam periode akuntansi. Sehingga semakin besar biaya penyusutan, maka semakin besar deductible expense dan pada akhirnya semakin kecil pajak terutang perusahaan.

Berdasarkan teori perilaku terencana yang menjelaskan tentang perilaku yang timbul dalam diri manusia atau individu karena adanya niat untuk berperilaku (Ajzen, 1991 dalam jurnal Karyada, 2020). Dalam perilaku teori terencana menjelaskan tentang bagaimana wajib pajak untuk melaksanakan kewajiban dalam membayar pajak. Jika yang 
berperilaku positif maka wajib pajak akan melakukan tugasnya untuk membayar pajak, namun jika ia berperilaku negatif maka wajib pajak akan berniat melakukan tindakan agresif terhadap pembayaran pajak. Dalam kaitannya dengan teori ini, seorang individu berperilaku negatif dengan melakukan tindakan Agresivitas Pajak. Hal ini disebabkan karena adanya intensitas modal.

Penelitian terdahulu yang membahas mengenai variabel intensitas modal, yakni penelitian oleh Hazir (2019) dengan judul Determinants of Effective Tax Rates in Turkey. Penelitian ini mencerminkan intensitas modal memiliki pengaruh negatif pada agresivitas pajak perusahaan. Berdasarkan uraian tersebut, hipotesis yang dikembangkan adalah: H1: Intensitas modal berpengaruh terhadap agresivitas pajak.

\section{Biaya utang berpengaruh terhadap agresivitas pajak}

Biaya Utang atau cost of debt merupakan tingkat pengembalian yang diinginkan oleh kreditur saat memberikan pendanaan kepada perusahaan ketika melakukan peminjaman (Arianti, 2019). Perusahaan menggunakan utang untuk membiayai investasi. Berdasaran teori perilaku terencana menjelaskan tentang perilaku yang timbul dalam diri manusia atau individu karena adanya niat untuk berperilaku (Ajzen, 1991 dalam jurnal Karyada, 2020). Dalam perilaku teori terencana menjelaskan tentang bagaimana wajib pajak untuk melaksanakan kewajiban dalam membayar pajak. Jika yang berperilaku positif maka wajib pajak akan melakukan tugasnya untuk membayar pajak, namun jika ia berperilaku negatif maka wajib pajak akan berniat melakukan tindakan agresif terhadap pembayaran pajak.. Dalam kaitannya dengan teori ini, seorang individu berperilaku negatif yaitu dengan melakukan tindakan Agresivitas Pajak. Hal ini disebabkan karena adanya biaya utang.

Berdasarkan hasil penelitian yang dilakukan oleh Yunita (2018); Arianti (2019), menyatakan bahwa Biaya Utang tidak berpengaruh terhadap Penghindaran Pajak.
Semakin banyak jumlah biaya hutang yang ditanggung oleh suatu perusahaan maka semakin meningkat pula perusahaan melakukan tindakan Agresivitas Pajak. Berdasarkan uraian tersebut, maka rumasan hipotesis, yaitu:

H2: Diduga Biaya Utang berpengaruh terhadap Agresivitas Pajak

\section{Komisaris independen dapat memoderasi hubungan intensitas modal terhadap agresivitas}

Intensitas Modal (capital intensity) merupakan seberapa besar perusahaan menginvestasikan asset tetap. Dimana asset tetap dapat memperlihatkan banyaknya kekayaan yang dimiliki oleh suatu perusahaan. Karena semakin besar perusahaan menggunakan investasi dalam bentuk asset tetap maka semakin banyak pula perusahaan menanggung beban depresiasi, beban tersebut yang akan mengurangi laba perusahaan sehingga dapat berpengaruh terhadap kewajiban perpajakan. Sehingga keberadaan komisaris independen dijadikan alasan sebagai variabel pemoderasi.

Berdasarkan teori perilaku terencana menjelaskan tentang perilaku yang timbul dalam diri manusia atau individu karena adanya niat untuk berperilaku (Ajzen, 1991 dalam jurnal Karyada, 2020). Dalam perilaku teori terencana menjelaskan tentang bagaimana wajib pajak untuk melaksanakan kewajiban dalam membayar pajak. Jika yang berperilaku positif maka wajib pajak akan melakukan tugasnya untuk membayar pajak, namun jika ia berperilaku negatif maka wajib pajak akan berniat melakukan tindakan agresif terhadap pembayaran pajak. Dalam kaitannya dengan teori ini, seorang individu berperilaku negatif dengan melakukan tindakan Agresivitas Pajak. Hal ini disebabkan karena adanya intensitas modal. Sehingga dengan adanya kehadiran komisaris independen di harapkan dapat meminimalisir oportunitas manajer yang mungkin dapat terjadi. Karena dengan adanya komisaris independen pengawasan yang di lakukan oleh dewan komisaris terhadap manajer semakin ketat 
atau mencegah manajer melakukan tindakan perilaku Agresivitas Pajak.

Berdasarkan penelitian yang dilakukan Aderia (2019) bahwa Komisaris Independen berpengaruh negatif terhadap Agresivitas Pajak. Berdasarkan uraian tersebut maka rumusan hipotesis ke tiga, yaitu:

H3: Diduga Komisaris Independen memperkuat hubungan Intensitas Modal terhadap Agresivitas Pajak

\section{Komisaris independen dapat memoderasi hubungan biaya utang terhadap agresivitas pajak}

Biaya Utang atau cost of debt merupakan tingkat pengembalian yang diinginkan oleh kreditur saat memberikan pendanaan kepada perusahaan ketika melakukan peminjaman (Arianti, 2019). Perusahaan menggunakan utang untuk membiayai investasi, kaitannya dengan perpajakan, perilaku ini dikarenakan bunga diklasifikasikan sebagai bahan tetap yang dapat mengurangi pajak, sehingga dengan adanya utang memberikan hubungan positif pada aktivitas agresivitas pajak. Sehingga keberadaan komisaris independen dijadikan alasan sebagai variabel pemoderasi.

Berdasarkan teori perilaku terencana menjelaskan tentang perilaku yang timbul dalam diri manusia atau individu karena adanya niat untuk berperilaku (Ajzen, 1991 dalam jurnal Karyada, 2020). Dalam perilaku teori terencana menjelaskan tentang bagaimana wajib pajak untuk melaksanakan kewajiban dalam membayar pajak. Jika yang berperilaku positif maka wajib pajak akan melakukan tugasnya untuk membayar pajak, namun jika ia berperilaku negatif maka wajib pajak akan berniat melakukan tindakan agresif terhadap pembayaran pajak. Dalam kaitannya dengan teori ini, seorang individu berperilaku negatif yaitu dengan melakukan tindakan Agresivitas Pajak. Hal ini disebabkan karena adanya biaya utang. Sehingga dengan adanya kehadiran komisaris independen di harapkan dapat meminimalisir oportunitas manajer yang mungkin dapat terjadi. Karena dengan adanya komisaris independen pengawasan yang di lakukan oleh dewan komisaris terhadap manajer semakin ketat atau mencegah manajer melakukan tindakan Agresivitas Pajak. Berdasarkan penelitian yang dilakukan oleh Aderia (2019) menyatakan bahwa Komisaris Independen berpengaruh negatif terhadap Agresivitas Pajak Berdasarkan uraian tersebut, dapat diuraikan rumusan hipotesis, sebagai berikut:

H4: Komisaris Independen memperkuat hubungan Biaya Utang terhadap Agresivitas Pajak.

\section{METODE PENELITIAN}

Jenis penelitian ini menggunakan jenis penelitian kuantitatif dan sumber data yang digunakan adalah data sekunder yang didapat melalui teknik pengumpulan data berupa laporan keuangan yang diunduh dari website Bursa Efek Indonesia atau www.idx.co.id. Teknik sampling yang digunakan dalam penelitian adalah teknik proposive sampling. ukuran dalam penentuan jumlah sampel menggunakan kriteria-kriteria tertentu sehingga di dapat jumlah sampel sebanyak 13 perusahaan. Populasi dalam penelitian ini yaitu perusahaan manufaktur yang terdaftar di Bursa Efek Indonesia periode 2016-2020 sebanyak 163 perusahaan. Teknik analisis data yang digunakan yaitu statistik deskriptif dan regresi data panel.

Menurut Sugiyono (2010:29) operasional variabel adalah melekat arti pada variabel dengan cara menetapkan kegiatan atau tindakan yang perlu untuk mengukur variabel itu. Definisi dan operasional variabel dimaksudkan untuk mengetahui pengaruh pengukuran variabel dalam penelitian ini. Variabel yang digunakan dalam penelitian ini terdapat 3 variabel, yaitu variabel dependen, variabel independen, dan variabel moderasi. Variabel dependen yang digunakan dalam penelitian adalah Agresivitas Pajak atau penghindaran pajak adalah cara untuk mengurangi pajak yang bersifat legalkarena tidak melanggar peraturan yang ada melainkan dengan memanfaatkan celah celah hukum perpajakan yang ada (Arianti, 2019), variabel independen yang digunakan yaitu Intensitas Modal merupakan salah satu 
bentuk keputusan keuangan yang di tetapkan oleh manajemen untuk meningkatkan profitabilitas perusahaan. Sedangkan Biaya Utang merupakan tingkat pengembalian sebelum pajak yang harus yang harus dibayar oleh perusahaan ketika melakukan pinjaman (Arianti, 2019). Komisaris Independen didefinisikan sebagai seorang yang tidak terafiliasi dalam segala hal dalam pemegang saham pengendali. Tidak memiliki hubungan afiliasi dengan direksi atau dewan komisaris, serta tidak menjabat sebagai direktur pada suatu perusahaan yang terkait (Arianti, 2020)

Tabel 1. Definisi Operasional Variabel

\begin{tabular}{lll}
\hline \multicolumn{1}{c}{ Variabel } & \multicolumn{1}{c}{ Indikator } & \multicolumn{1}{c}{ Sumber } \\
\hline$\frac{\text { Intensitas }}{\text { Modal }(X 1)}$ & $\frac{\text { Total Aset tetap }}{\text { Botal Aset }}$ & (Mulyani et al, 2014) \\
$\frac{\text { Biaya utang }}{(X 2)}$ & $\frac{\text { Biaya Utang }}{\text { rata-rata utang }}$ & (Arianti, 2019) \\
Agresivitas Pajak $(\mathrm{Y})$ & $\frac{\text { Beban PPh }}{\text { laba sebelum pajak }}$ & (Bachtiar, 2015) \\
Komisaris Independen $(\mathrm{Z})$ & $\frac{\text { jml komisaris independen }}{\text { total dewan komisaris }}$ & (Arianti, 2020) \\
\hline
\end{tabular}

Metode analsisa data adalah suatu kegiatan yang dilakukan untuk memproses dan menganalisis data yang telah terkumpul. Dalam penelitian ini, peneliti menggunakan analisis kuantitatif. Analisis kuantitatif merupakan suatu bentuk analisis yang diperuntukkan bagi data yang besar yang dikelompokkan ke dalam kategori-kategori yang berwujud angka-angka. Metode analisis data menggunakan metode regresi data panel. Data panel ( $\mathrm{Pool}$ ) merupakan gabungan antara data runtun waktu (time series) dengan data silang (cross sction). Metode kuadrat kecil atau metode Ordinary Least Squared (OLS) dengan beberapa uji yaitu terdiri dari Analisis Statistik
Deskriptif, Data Panel, Uji Asumsi Klasik, Regresi Analisis Berganda, Moderate Reggesion Analysis, Uji Koefisien Determinasi $\left(\mathrm{R}^{2}\right)$ dan Uji Hipotesis dengan bantuan komputer melalui Microsoft Excel dan program Eviews 9.

\section{HASIL DAN PEMBAHASAN}

Analisis statistik deskriptif mendeskripsikan mengenai ringkasan persebaran nilai minimal, nilai maksimal, nilai mean, nilai median dan standar devisiasi dari masing-masing variabel. Berikut ini merupakan gamabaran dari persebaran data seluruh variabel:

Tabel 2. Statistik Deskriptif Variabel

\begin{tabular}{lllllll}
\hline Variabel & $\mathrm{N}$ & Min & Max & Mean & Median & Standar deviasi \\
\hline Intensitas modal & 65 & 0.13 & 0.56 & 0.32 & 0.32 & 0.12 \\
Biaya utang & 65 & 0.00 & 0.14 & 0.04 & 0.03 & 0.03 \\
Komisaris independen & 65 & 0.33 & 0.6 & 0.39 & 0.37 & 0.08 \\
Agresivitas pajak & 65 & 0.17 & 0.32 & 0.24 & 0.24 & 0.02 \\
\hline
\end{tabular}

Sumber: output e-view 9

Berdasarkan tabel 2 diatas, kolom N menjelaskan 65 data obesrevasi yang digunakan dalam penelitian. Variabel Agresivitas Pajak memiliki nilai rata-rata sebesar 0,24 artinya tindakan Agresivitas Pajak yang dilakukan oleh perusahaan manufaktur yang terdaftar di BEI tahun 2016-2020 sebesar 24 persen. Agresivitas pajak paling rendah adalah 0.17 diperoleh dari perusahaan Tempo Scan Pacific Tbk (TSCP). Sementara agresivitas pajak paling tinggi adalah sebesar 0,324 diperoleh dari perusahaan Kedawung Setia 
Industrial Tbk (KDSI) kenaikan terjadi pada tahun 2019. Sedangkan standar devisiasi sebesar 0,02 .

Variabel Intensitas Modal memiliki nilai rata-rata dari perusahaam manufaktur yang terdaftar di BEI tahun 2016-2019 sebesar 0,32 atau 32 persen dan nilai median sebesar 0,32 . Nilai tertinggi yaitu 0,56 terjadi pada tahun 2016 yang diperoleh dari perusahaan Multi Bintang Indonesia Tbk (MLBI). Nilai terendah sebesar 0,33 yang diperoleh dari perusahaan Supreme Cable Manufacturing \& Commerce $\mathrm{Tb}$ (SCCO). Sedangkan standar devisiasinya sebesar 0,12.

Variabel Biaya utang memiliki nilai rata-rata dari perusahaan manufaktur yang terdaftar di BEI tahun 2016-2020 sebesar 0,04 dan nilai median sebesar 0,03 . Nilai tertinggi yaitu 0,14 diperoleh dari perusahaan Kedawung Setia Industrial Tbk (KDSI). Nilai terendah sebesar 0,00 diperoleh dari

Tabel 3. Hasil Pengujian Hipotesis

\begin{tabular}{|c|c|c|c|c|c|c|}
\hline \multirow[t]{3}{*}{ Variable } & \multicolumn{6}{|c|}{ Agresivitas pajak } \\
\hline & & Model 1 & & & Model 2 & \\
\hline & coefficient & t-stat & Prob & coefficient & t-stat & Prob \\
\hline $\mathrm{C}$ & 0.21 & 18.5 & 0.00 & 0.02 & 17.6 & 0.00 \\
\hline IM & 0.07 & 2.21 & 0.03 & 0.26 & 2.57 & 0.01 \\
\hline BU & 0.08 & 0.98 & 0.32 & -1.32 & -2.54 & 0.01 \\
\hline $\mathrm{KI}^{*} \mathrm{IM}$ & & & & -0.53 & -1.99 & 0.05 \\
\hline $\mathrm{KI}{ }^{*} \mathrm{BU}$ & & & & 3.89 & -2.73 & 0.00 \\
\hline $\mathrm{R}^{2}$ & 0.09 & & & 0.19 & & \\
\hline Adjusted R² & 0.06 & & & 0.13 & & \\
\hline F-stat & 3.19 & & 0.04 & 3.56 & & 0.01 \\
\hline
\end{tabular}

Sumber: output e-views 9

Berdasarkan hasil analisis data panel yang dilakukan pada tabel 3, nilai Adjusted $R^{2}$ untuk model 1 adalah 0,06 . Hal ini berarti bahwa variabel independen intensitas modal dan biaya utang mampu mempengaruhi variabel dependen yaitu agresivitas pajak sebesar 6\% dan sisanya senilai $94 \%$ agresivitas pajak dipengaruhi oleh faktor-faktor diluar model. Sementara itu, Adjusted $R^{2}$ pada model 2 memiliki nilai sebesar 0,13 . Hal ini mengindikasikan bahwa $13 \%$ variabel agresivitas pajak dapat dipengaruhi oleh seluruh variabel independen, yaitu intensitas modal, biaya utang, interaksi antara komisaris perusahaan Wilmar Cahaya Indonesia Tbk (CEKA) terjadi pada tahun 2020. Sedangkan standar devisiasinya sebesar 0,03.

Variabel Komisaris independen memiliki nilai rata-rata dari perusahaan manufaktur yang terdaftar di BEI tahun 20162020 sebesar 0,39 atau 39 persen dan nilai median sebesar 0,37. Nilai tertinggi yaitu 0,6 diperoleh dari perusahaan Tempo Scan Pacific Tbk (TSCP), nilai terendah sebesar 0,04 diperoleh dari perusahaan Arwana Citramulia Tbk (ARNA). Sedangkan standar devisiasinya sebesar 0,082

Hasil dari pengujian hipotesis dijabarkan menjadi dua bagian, yaitu hasil analisis data panel tanpa moderasi (model 1) dan hasil analisis data panel dengan moderasi (model 2) yang dijabarkan pada tabel 3 sebagai berikut: 
Artinya intensitas modal berpengaruh signifikan dan positif terhadap agresivitas pajak. Sesuai dengan teori perilaku terencana mengatakan tentang perilaku yang timbul dalam diri manusia atau individu karena adanya niat untuk berperilaku. Dimana Intensitas Modal merupakan asset tetap yang dapat memperlihatkan banyaknya kekayaan yang dimiliki oleh suatu perusahaan. Semakin banyak perusahaan menggunakan asset tetap maka semakin besar pula perusahaan menanggung beban depresiasinya, dari beban depresiasi inilah yang memyebabkan pihak perusahaan melakukan tindakan negatif yaitu dengan melakukan tindakan Agresivitas Pajak. Hasil ini mendukung penelitian terdahulu yang dilakukan oleh Rasulita (2018), Ariyani et al (2019), Darsani et al (2021). Sedangkan penelitian ini bertolak belakang dengan penelitian yang dilakukan oleh Savitri dan Rahmawati (2017).

Hasil pengujian untuk hipotesis kedua menunjukkan nilai t-statistic sebesar 0,98 dan nilai prob sebesar 0,32. Dikarekan nilai tstatistic < 1.99, maka hipotesis kedua ditolak. Artinya Biaya utang tidak berpengaruh terhadap agresivitas pajak. Sesuai dengan teori perilaku terencana yang mengatakan tentang perilaku yang timbul dalam diri manusia atau individu karena adanya niat untuk berperilaku. Dimana semakin banyak perusahaan menanggung utang, maka semakin banyak pula beban bunga yang ditanggung oleh perusahaan. Namun tidak menimbulkan perilaku negatif bagi perusahaan untuk melakukan tindakan Agresivitas Pajak. Maka pihak manajemen akan lebih konservatif dalam melakukan pelaporan keuangan atas operasional perusahaan (Hidayat, 2018). Hasil ini mendukung penelitian terdahulu yang dilakukan oleh Yunita (2018) sedangkan penelitian ini bertolak belakang dengan penelitian yang dilakukan oleh kalbuana et al (2020).

Hasil pengujian untuk hipotesis ketiga menunjukkan nilai t-statistic sebesar -1,99 dan nilai prob sebesar 0,05. Dikarenakan nilai tstatistic < 1.99, maka hipotesis ketiga ditolak.
Artinya komisaris independen tidak dapat memoderasi hubungan intensitas modal terhadap agresivitas pajak. Sesuai dengan teori perilaku terencana yang mengatakan tentang perilaku yang timbul dalam diri manusia atau individu karena adanya niat untuk berperilaku. Dimana kehadiran komisaris independen tidak mempengaruhi hubungan antara Intensitas modal dengan agresivitas pajak. Semakin banyak perusahaan menggunakan asset tetap maka semakin besar pula perusahaan melakukan tindakan negatif yaitu dengan melakukan tindakan Agresivitas Pajak.

Hasil penelitian untuk hipotesis keempat menunjukkan nilai t-statistic sebesar -2,73 dan nilai prob sebesar 0,00 . Dikarenakan nilai tstatistik > 1.99, maka hipotesis keempat diterima. Artinya komisaris independen dapat memoderasi hubungan biaya utang terhadap agresivitas pajak. Sesuai dengan teori perilaku terencana yang mengatakan tentang perilaku yang timbul dalam diri manusia atau individu karena adanya niat untuk berperilaku. Dimana semakin banyak perusahaan menanggung utang, maka semakin besar pula perusahaan menganggung beban bunga. Dari beban bunga inilah yang memyebabkan perusahaan melakukan tindakan negatif yaitu dengan melakukan tindakan agresivitas pajak. Sehingga keberadaan komisaris independen berfungsi untuk mengawasi sistem manajemen perpajakan dalam perusahaan agar tidak terjadi tindakan agresivitas pajak.

\section{SIMPULAN}

Berdasarkan Hasil penelitian yang dilakukan, maka dapat disimpulkan bahwa intensitas modal berpengaruh positif dan signifikan terhadap agresivitas pajak dan biaya utang tidak berpengaruh signifikan terhadap agresivitas pajak. Sedangkan komisaris independen tidak dapat memoderasi atau memperlemah pengaruh intensitas modal terhadap agresivitas pajak. Serta komisaris independen dapat memoderasi atau memperkuat pengaruh biaya utang terhadap agresivitas pajak. 
Keterbatasan dalam penelitian ini yaitu populasi dan sampel dalam penelitian ini hanya berfokus pada perusahaan manufaktur, variabel independen yang digunakan dalam penelitian ini hanya intensitas modal dan biaya utang dengan 1 variabel moderasi yaitu komisaris independen, dalam penelitian ini hanya menggunakan 5 tahun periode yaitu 2016-2020, dan pengukuran pendekatan pengukuran agresivitas pajak yang digunakan yaitu effective tax rate.

Saran dalam penelitian ini yaitu Untuk pemerintah dimohonkan lebih memperketat penjagaan terhadap perusahaan yang melaporkan kewajiban perpajakan khususnya perusahaan yang memiliki jumlah asset tetap dan utang yang cukup besar, Dalam penelitian ini masih banyak kekurangan yang perlu diperbaiki dan dikembangkan. Bagi peneliti selanjutnya dapat menambahkan variabel lain misalnya Likuiditas, ROE, ROA, dan CSR yang berkaitan dengan variabel penelitian ini, Untuk peneliti selanjutnya dimohonkan dapat melakukan penelitian yang serupa dengan objek penelitian yang berbeda terutama pada perusahaan yang telah go public, dan Bagi akademisi penelitian ini dapat dijadikan bahan referensi dan dokumentasi dalam melakukan penelitian selanjutnya.

\section{REFERENSI}

Aderia, M. (2019). Pengaruh Capital Intensity, Inventory intensity dan Komisaris independen terhadap Agresivitas Pajak pada Perusahaan sub sektor makanan dan minuman yang terdaftar di Bursa Efek indonesia periode 2013-2017. Skripsi. Universitas Sriwijaya. Palembang.

Arianti, B. F. (2019). Pengaruh Pengungkapan Sukarela, Penghidaran Pajak dan Corporate Governace terhadap Biaya Hutang. Journal of Economic and Management Scienties, 2(1), 14-29.

Arianti, B. F. (2020). The Effect of Independent Commissioner's Moderation of CSR and Institutional Ownership on Tax Avoidance. Jabe (Journal of Accounting and Business Education), 4(2), 98. https://doi.org/10.26675/jabe.v4i2.8271

Ariyani, P., Lestari, S., Pratomo, D., \& Asalam, A. G. (2019). Pengaruh Koneksi Politik dan Capital Intensity Terhadap Agresivitas Pajak. Jurnal ASET (Akuntansi Riset), 11(1), 41-54. https://doi.org/10.17509/jaset.v11i1.1 5772

Ayem, S., \& Setyadi, A. (2019). Pengaruh Profitabilitas, Ukuran Perusahaan, Komite Audit Dan Capital Intensity Terhadap Agresivitas Pajak ( Studi Pada Perusahaan Perbankan Yang Terdaftar di BEI Periode Tahun 2013-. Jurnal Akuntansi Pajak Dewantara, 1(2), 228-241. https://doi.org/10.24964/japd.v1i1.90 5

Darsani, P. A., \& Sukartha, I. M. (2021). The Effect of Institutional Ownership, Profitability, Leverage and Capital Intensity Ratio on Tax Avoidance. American Journal of Humanities and Social Sciences Research (AJHSSR), 5(1), 13-22. https://www.ajhssr.com/wpcontent/uploads/2021/01/C215011322 .pdf

Dwi Sandra, M. Y., \& Anwar, A. S. H. (2018). Pengaruh Corporate Social Responsibility Dan Capital Intensity Terhadap Penghindaran Pajak. Jurnal Akademi Akuntansi, 1(1), 1-8. https://doi.org/10.22219/jaa.v1i1.6947

Eksandy, A. (2014). Pengaruh komisaris independen, komite audit, dan kualitas audit terhadap penghindaran pajak ( Studi Empiris Pada Sektor Industri Barang Konsumsi yang terdaftar di Bursa Efek Indonesia Periode 2010-2014 ). Competitive, 1(1), 1-20.

Hazir, Cagri Aksoy. (2019). Determinants Of Effective Tax Rate In Turkey. Journal of Research in Business 4(1):35-45

Kalbuana, N., Solihin, S., Saptono, S., Yohana, Y., \& Yanti, D. R. (2020). The Influence of Capital Intensity, Firm Size, and Leverage on Tax Avoidance on Companies Registered in Jakarta Islamic Index (JII) Period 2015-2019. 
International Journal of Economics, Business and Accounting Research (IJEBAR), 4(3), 272-278. https:/ jurnal.stieaas.ac.id/index.php/IJEBAR/article/v iew $/ 1330 / 727$

Maulana, M., Marwa, T., \& Wahyudi, T. (2018). The Effect of Transfer Pricing, Capital Intensity and Financial Distress on Tax Avoidance with Firm Size as Moderating Variables. Modern Economics, 11(1), 122-128. https://doi.org/10.31521/modecon.v1 1(2018)-20

Muliawati, I. A. P. Y., \& Karyada, P. F. (2020). Pengaruh leverage dan capital intensity terhadap agresivitas pajak dengan komisaris independen sebagai variabel pemoderasi. Hita Akuntansi Dan Keuangan, 495-524.

Muzakki, Muadz Rizki \& Darsono. (2015). Pengaruh Corporate Social Responsibility Dan Capital Intensity Terhadap Penghindaran Pajak. Diponegoro Journal Of Accounting 4(3):1-8.

Noviyani, E., \& Muid, D. (2019). Pengaruh Return on Assets, Leverage, Ukuran Perusahaan, Intensitas Aset Tetap, dan Kepemilikan Institusional terhadap Penghindaran Pajak. Diponegoro Journal of Accounting, 8(3), 1-11.
Putri, V. R. (2020). Berpengaruhkah Asset intensity dan Debt Policy terhadap penghindaran pajak. Jurnal Akuntansi Keuangan Dan Bisnis, 13(2), 118-125. http://repository.ibs.ac.id/1878/

Rahmadi, Z. T., \& Suharti, E. (2018). Pengaruh Capital Intensity dan Leverage Terhadap Agresivitas Pajak pada Perusahaan Manufaktur yang Terdaftar di Bursa Efek Indonesia ( BEI ) Periode 2014-2018. Skripsi. Sekolah Tinggi Ilmu Ekonomi. Batam

Savitri, D. A. M., \& Rahmwati, I. N. (2017). Pengaruh leverage, intensitas persediaan, intensitas aset tetap, dan profitabilitas terhadap agresivitas pajak. Jurnal Ilmu Manajemen Dan Akuntansi Terapan, 8(November), 64-79.

Suyanto, K. D., \& Supramono. (2012). Likuiditas, leverage, komisaris independen, dan manajemen laba terhadap agresivitas pajak perusahaan. Jurnal Keuangan Dan Perbankan, 16(2), 167-177.

Wulansari, T. A., Titisari, K. H., \& Nurlaela, S. (2020). Pengaruh leverage, intensitas persediaan, aset tetap, ukuran perusahaan, komisaris independen terhadap agresivitas pajak. Jurnal Akuntansi \& Ekonomi, 5(1), 69-76. 